Tropical Journal of Pharmaceutical Research March 2020; 19 (3): 609-615

ISSN: $1596-5996$ (print); 1596-9827 (electronic)

(C) Pharmacotherapy Group, Faculty of Pharmacy, University of Benin, Benin City, 300001 Nigeria.

\title{
Hepatoprotective effect of desi and kabuli cultivars of Cicer arietinum $L$ (chick peas) against carbon tetrachloride-induced toxicity in rats
}

\author{
Mudasir Majeed1, Abdullah ljaz Hussain ${ }^{2 *}$, Haseeb Anwar ${ }^{3}$, Shahzad Irfan³, \\ Shahzad Ali Shahid Chatha ${ }^{2}$, Qasim Ali ${ }^{4}$, Imran Mukhtar ${ }^{3}$, Zahra Hafeez $^{5}$ \\ ${ }^{1}$ Department of Applied Chemistry, ${ }^{2}$ Natural Product and Synthetic Chemistry Laboratory, Department of Chemistry, \\ ${ }^{3}$ Department of Physiology, ${ }^{4}$ Department of Botany, Government College University, ${ }^{5}$ Department of Botany, University of \\ Agricultural, Faisalabad, Pakistan
}

*For correspondence: Email: abdullahijaz@gcuf.edu.pk; Tel: +92-300-7631058

Sent for review: 16 October 2019

Revised accepted: 22 February 2020

\begin{abstract}
Purpose: To determine the hepatoprotective potential of ethanol extracts of desi and kabuli cultivars of Cicer arietinum L. (chick peas).

Methods: Hepatotoxicity was induced in rats using oral administration of carbon tetrachloride (CC/4). The rats were then orally administered different doses of the ethanol extracts of desi and kabuli cultivars of Cicer arietinum L. for 21 days. Oxidative stress parameters and hepatoprotective profiles were determined in serum samples using standard procedures. The effect of the treatments on liver histology was also determined.

Results: Administration of extracts of desi and kabuli cultivars of Cicer arietinum L. to $\mathrm{CCl}_{4}$ treated rats at a dose of $300 \mathrm{mg} / \mathrm{kg}$ resulted in a significant $(p \leq 0.05)$ decrease in oxidative stress parameters, whereas catalase activity significantly increased ( $p \leq 0.05$ ); on the other hand, ALT and AST levels were decreased significantly ( $p \leq 0.05)$, when compared to the control group.

Conclusion: High doses of Cicer arietinum L (desi and kabuli cultivars) seem to have hepatoprotective and antioxidant effects on $\mathrm{CCl}_{4}$-induced toxicity in rats. This finding underscores the therapeutic importance of Cicer arietinum L. as a plant with hepatoprotective properties.
\end{abstract}

Keywords: Cicer arietinum, Phenolics, Hepatotoxicity, Chick peas, Catalase

\begin{abstract}
This is an Open Access article that uses a fund-ing model which does not charge readers or their institutions for access and distributed under the terms of the Creative Commons Attribution License (http://creativecommons.org/licenses/by/4.0) and the Budapest Open Access Initiative (http://www.budapestopenaccessinitiative.org/read), which permit unrestricted use, distribution, and reproduction in any medium, provided the original work is properly credited.
\end{abstract}

Tropical Journal of Pharmaceutical Research is indexed by Science Citation Index (SciSearch), Scopus, International Pharmaceutical Abstract, Chemical Abstracts, Embase, Index Copernicus, EBSCO, African Index Medicus, JournalSeek, Journal Citation Reports/Science Edition, Directory of Open Access Journals (DOAJ), African Journal Online, Bioline International, Open-J-Gate and Pharmacy Abstracts

\section{INTRODUCTION}

Cicer arietinum L. (desi and Kabuli) is a leguminous pulse which belongs to the Fabaceae family. It has high nutritional profile and it is a good source of minerals and unsaturated fatty acids [1]. Cicer arietinum L. also contains bioactive compounds like polyphenols, antioxidants and vitamins which play vital roles in enhancing immunity against cardiovascular and metabolic diseases, as well as cancer [2]. In general, daily intake of legumes has beneficial effect in the management of various chronic heart conditions and metabolic diseases [3]. Cicer arietinum L. also contains sugars and proteins. Meat is a good source of 
protein [4]. However, meat is more expensive and more scarce than plant-based proteins, and it contributes significantly more to global warming than Cicer arietinum L. [5]. Moreover, legumes are used by vegetarians as a meat substitute for protein and energy, so much so that they are referred to as 'the poor man's meat' [5].

Studies have associated Cicer arietinum L. with hypocholesterolemia due to its contents of various biological components such as phytic acid and complex proteins [6-8]. Legumes contain various micronutrients such as watersoluble vitamins, fat-soluble vitamins, macro minerals and trace minerals [9,10]. Globally, plant-based diets are now frequently used as relatively cheap sources of valuable nutrients which are normally required by humans $[11,12]$.

Limited data are available on the nutritional and compositional status, and the bioactive potential of Cicer arietinum L. However, not much is known on the biological role of Cicer arietinum $\mathrm{L}$. with respect to its hepatoprotective effect. Plantbased antioxidant compounds are safer and more beneficial than synthetic compounds.

The aim of this research was to investigate the hepatoprotective potential of the ethanol extract of Cicer arietinum L. in rats.

\section{EXPERIMENTAL}

\section{Collection of Cicer arietinum L.}

Newly-developed high-yield lines of Cicer arietinum L. (desi and kabuli) named Balkasar and COOP-6 were chosen during the sowing season from mid-September to mid-November, 2018 at Ayub Research Centerand Punjab, Pakistan. Fully mature seed pod samples of the chick peas were selected and collected. The samples were authenticated Dr. Hameed from Botany Department, University of Agricultural, Faisalabad. A voucher sample (no. Ch-Am-2018) was kept in the departmental herbarium.

\section{Preconditioning and storage of seeds}

Seeds from the selected lines of Cicer arietinum $\mathrm{L}$. were removed from their dried black pods and washed with water to remove unwanted matter e.g. dust particles. Thereafter, a paper towel was used to remove any residual water from the seeds. Then, the seeds were air-dried until a constant weight was obtained. The dried seeds were milled with an electric miller, and the resultant course powder was preserved in sealed containers.

\section{Extract preparation}

Ethanol extracts were prepared according to the method previously described, using orbital shaker with absolute ethanol and $80 \%$ aqueous ethanol (80:20 ethanol:water, v/v) [13]. The ethanolic extracts were concentrated in a rotary evaporator (SciLogix Re-100 Pro) and kept at -4 ${ }^{\circ} \mathrm{C}[14]$.

\section{Animals, diet and in vivo studies}

Twenty-four albino rats aged 8 - 10 weeks (mean weight $=150 \pm 7.5 \mathrm{~g}$ ) were used in the study. The experimental rats were housed in a room with all standard facilities, and were provided ad libitum access to drinking water and normal diet. The rats were acclimatized for 7 days in the animal room with 12-h light/12-h dark cycle at 26 ${ }^{\circ} \mathrm{C}$ and $40-60 \%$ relative humidity. They were weighed weekly, and the daily amount of feed consumed by the animals was determined. The experimental rats were randomly assigned to 6 groups: negative control (NC), positive control (PC), high-dose desi Cicer arietinum L. group (G1A), low-dose desi Cicer arietinum L. group (G1B), high-dose kabuli Cicer arietinum L. group (G2A), and low-dose kabuli Cicer arietinum L. group (G2B). Each group had 4 rats in it $(n=4)$. Table 1 shows the details of treatments and doses used in the various groups. The ethanolic extract of balkaser cultivar of desi Cicer arietinum L. and COOP-6 cultivar of kabuli Cicer arietinum $\mathrm{L}$. were administered orally (300 and $150 \mathrm{mg} / \mathrm{kg}$ ) for 21 days. The experiment was carried out in accordance with the guidelines outlined by the American Association for Laboratory Animal Science (AALAS) rules for ethical use of laboratory animals in research [15]. The current study was also certified by Government College University Faisalabad, and Ethical Committee for Animal Care (IRB no. 211; study no. 20189: Ref no. GCUF/ERC: 211).

Rats in all the groups were sacrificed on the $22^{\text {nd }}$ day of experiment after regular oral administration of ethanolic extract of Cicer arietinum L. Blood was collected in vacuum containers without anticoagulant, and serum samples were obtained by centrifuging the blood samples for $4 \mathrm{~min}$ at $4000 \mathrm{~g}$. The serum was analyzed for total antioxidant capacity (TAC) and total oxidative stress (TOS) potential according to the methods described earlier [16]. Hydrogen peroxide $\left(\mathrm{H}_{2} \mathrm{O}_{2}\right)$ standard curve was prepared using a concentration range of 0.38-6.26 $\mu \mathrm{mol} / \mathrm{L}$, and was used to measure the TOS of selected serum samples. 
Table 1: Grouping and animal treatments

\begin{tabular}{|c|c|}
\hline Group & Diet and treatment \\
\hline Negative control (NC) & Commercial chow normal diet (CMD) for 21 days \\
\hline Positive control (PC) & Single oral dose of $\mathrm{CCl}_{4}$ in olive oil $(1: 1 \mathrm{v} / \mathrm{v})$ on day 14 \\
\hline G1A & $\begin{array}{l}\text { CMD for } 21 \text { days } \\
\text { Single oral dose }\left(\mathrm{CCl}_{4}+\text { Olive oil } 1: 1 \mathrm{v} / \mathrm{v}\right) \text { on day } 14 \\
\text { Daily oral dose of desi (Cicer arietinum L.) extract at a dose of } 300 \mathrm{mg} / \mathrm{kg} \text { bwt for } 21 \\
\text { days; }\end{array}$ \\
\hline G1B & $\begin{array}{l}\text { CMD for } 21 \text { days, } \\
\text { Single oral dose of } \mathrm{CCl}_{4} \text { in olive oil }(1: 1 \mathrm{v} / \mathrm{v}) \text { on day } 14 \\
\text { Daily oral dose of desi (Cicer arietinum L.) extract }(150 \mathrm{mg} / \mathrm{kg} \mathrm{bwt}) \text { for } 21 \text { days; }\end{array}$ \\
\hline G2A & $\begin{array}{l}\text { CMD for } 21 \text { days, } \\
\text { Single oral dose of } \mathrm{CCl}_{4} \text { in olive oil }(1: 1 \mathrm{v} / \mathrm{v}) \text { on day } 14 \\
\text { Daily oral dose of kabuli (Cicer arietinum L.) extract }(300 \mathrm{mg} / \mathrm{kg} \text { bwt) for } 21 \text { days }\end{array}$ \\
\hline G2B & $\begin{array}{l}\text { CMD for } 21 \text { days, } \\
\text { Single oral dose of } \mathrm{CCl}_{4} \text { in olive oil }(1: 1 \mathrm{v} / \mathrm{v}) \text { on day } 14 \text { Daily oral dose of kabuli (Cicer } \\
\text { arietinum } \mathrm{L} \text {.) extract }(150 \mathrm{mg} / \mathrm{kg} \text { bwt) for } 21 \text { days }\end{array}$ \\
\hline
\end{tabular}

The lowest measurable concentration was 0.13 $\mu \mathrm{mol} \mathrm{H}_{2} \mathrm{O}_{2} \mathrm{~L}^{-1}$, with less than $3 \%$ precision. The linearity of $\mathrm{H}_{2} \mathrm{O}_{2} \mathrm{~L}^{-1}$ was maintained at $200 \mu \mathrm{mol}$, and intra-assay CV was kept below $10 \%$. Trolox standard curve was prepared using a concentration range of $0.1-1.5 \mathrm{mmol} / \mathrm{L}$ for determination of TAC of the samples, and the results were expressed in $\mathrm{mmol}$ of TroloxL $\mathrm{L}^{-1}$. The lowest measurable concentration was $0.18 \mathrm{mmol}$ Trolox $\mathrm{L}^{-1}$, with less than $3 \%$ precision. The linearity of $\mathrm{H}_{2} \mathrm{O}_{2} \mathrm{~L}^{-1}$ was maintained at $6 \mathrm{mmol}$, while intra-assay $\mathrm{CV}$ was $<3 \%$. Aspartate aminotransferase (AST) and alanine aminotransferase (ALT) activities were assayed using Randox kits. The ranges of detection for ALT and AST were 7.20 - $1039 \mathrm{U} / \mathrm{L}$ and 9.7 $603 \mathrm{U} / \mathrm{L}$, respectively. Catalase was assayed using the method as previously described [17].

\section{Statistical analysis}

All analyses of serum samples were performed in triplicate. Data are presented as mean \pm SD. All statistical analyses were carried out with GraphPad Prism 6.0, using one-way (ANOVA). Differences were assumed statistically significant at $p \leq 0.05$.

\section{RESULTS}

\section{Yield of extracts}

The extract yields from lines of desi and kabuli Cicer arietinum L. varied significantly, with values in the range of $4.78 \pm 0.23-10.16 \pm 0.51 \mathrm{~g} / 100 \mathrm{~g}$ dry weight. Overall, extract yield from kabuli Cicer arietinum L. (COOP-6) was significantly higher than that from desi Cicer arietinum L. cultivar balkasar $(p \leq 0.05)$. These results are shown in Figure 1.

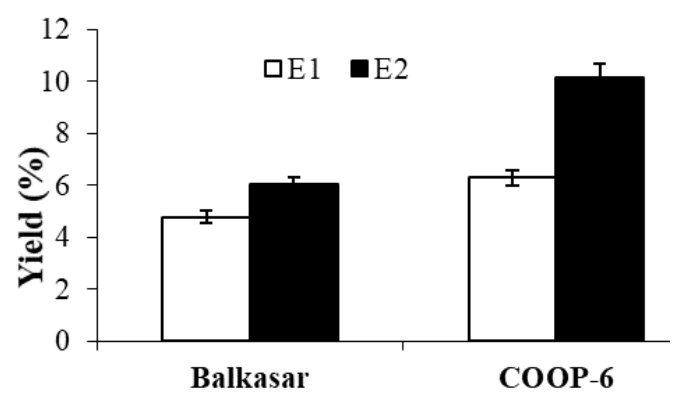

Figure 1: Extract yields from desi and kabuli Cicer arietinum L. E1: absolute ethanol extract; E2: $80 \%$ ethanol extract

\section{Change in body weights of rats}

The mean body weight of rats used in the current study was unchanged during the treatment period Figure 2.

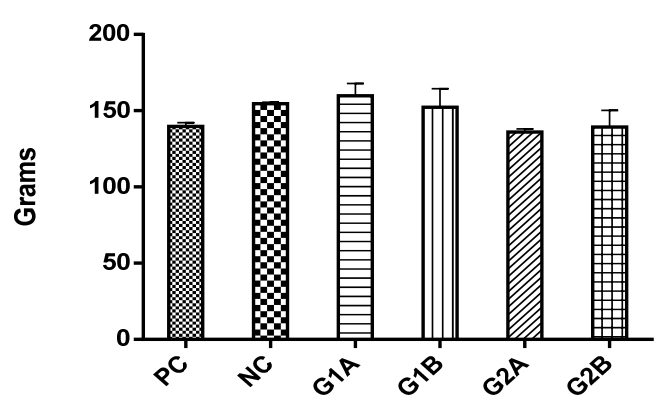

Figure 2: Body weights of rats $(g \pm S E)$ in different groups: PC: +ve control treated with $\mathrm{CCl}_{4}$ only; $\mathrm{NC}$ : ve control $\left(\mathrm{CCl}_{4}\right.$ without any treatment; $\mathrm{G} 1 \mathrm{~A}$ : Desi Cicer arietinum L. extract (300mg/kg bwt), G1B: desi Cicer arietinum L. extract (150mg/kg bwt), G2A: kabuli Cicer arietinum L. extract (300mg/kg bwt), and kabuli Cicer arietinum L. extract (150mg/kg bwt) 


\section{Total oxidant status}

As shown in Figure 3, mean serum TOS was markedly $(p \leq 0.05)$ reduced in $\mathrm{G} 1 \mathrm{~A}(2.54 \pm 0.42)$, G1B (2.81 \pm 0.33$), \quad$ G2A $\quad(6.47 \pm 0.27), \quad$ G2B $(6.62 \pm 0.51$ and NC (6.33 \pm 0.29$)$ groups, when compared to PC group (7.70 \pm 0.58$)$. Moreover, serum TOS values in G1A and G1B groups were significantly lower than those of G2A and G2B groups $(p \leq 0.05)$.

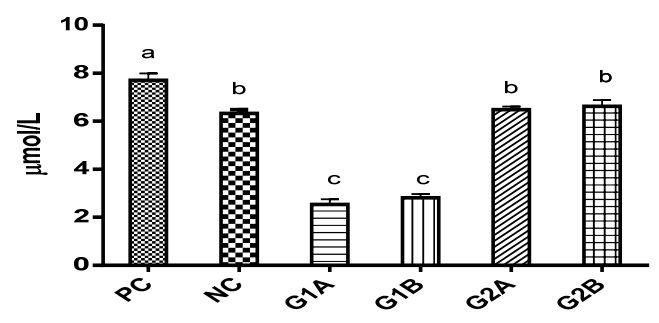

Figure 3: Mean serum TOS levels. Values are expressed as $\mu \mathrm{mol}$ of $\mathrm{H}_{2} \mathrm{O}_{2}$ equiv $L^{-1} \pm$ SEM). PC: positive control group treated with $\mathrm{CCl}_{4}$ only, $\mathrm{NC}$ : negative control group (untreated), G1A: desi Cicer arietinum L. extract group (300 mg/kg), G1B: desi Cicer arietinum L. extract group (150 mg/kg), G2A: kabuli Cicer arietinum L. extract group (30 $0 \mathrm{mg} / \mathrm{kg})$, and G2B: kabuli Cicer arietinum L. extract $(150 \mathrm{mg} / \mathrm{kg}$ bwt). All treatments were given orally for 21 days

\section{Total antioxidant capacity}

Mean serum TAC levels were markedly increased ( $p \leq 0.05)$ in G1B group $(2.78 \pm 0.08)$ and $\mathrm{G} 1 \mathrm{~A}$ group $(2.38 \pm 0.20)$ than in $\mathrm{PC}$ and $\mathrm{G} 2 \mathrm{~B}$ groups. Moreover, TAC level was higher $(p$ $\leq 0.05$ ) in G2A, G2B and NC groups than in PC group. These results are presented in Figure 4.

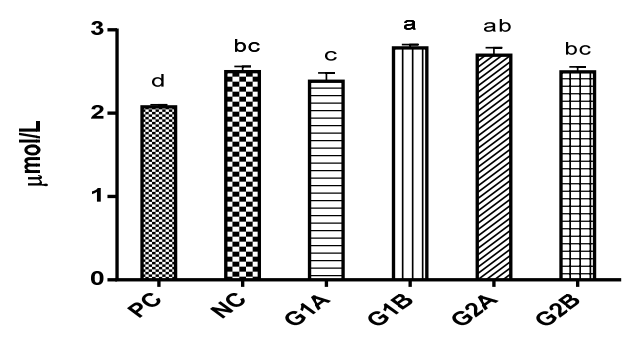

Figure 4: Mean serum TAC ofn the various groups. Values are expressed as $\mathrm{mmol}_{\text {of }}$ Trolox equiv $\mathrm{L}^{-1} \pm$ SEM. PC: positive control group treated with $\mathrm{CCl}_{4}$ only, NC: negative control group (untreated), G1A: desi Cicer arietinum L. extract group (300mg/kg), G1B: desi Cicer arietinum L. extract group (150mg/kg), G2A: kabuli Cicer arietinum L. extract group (300 mg/kg), and G2B: kabuli Cicer arietinum L. extract (150 mg/kg). All treatments were given orally for 21 days

\section{Changes in serum ALT}

There was a significant $(p \leq 0.05)$ decrease in mean serum ALT in G1B group (66.63 \pm 26.71 $\mathrm{U} / \mathrm{L}$ ), when compared to PC group (177.70 \pm 13.78U/L). In addition, ALT was markedly lowered $(p \leq 0.05)$ in G1A group $(86.18 \pm 24.67)$, G2Agroup (103.33 \pm 24.19$)$ and G2B group (119 \pm 16.14 ), relative to $P C$ group. These results are shown in Figure 5.

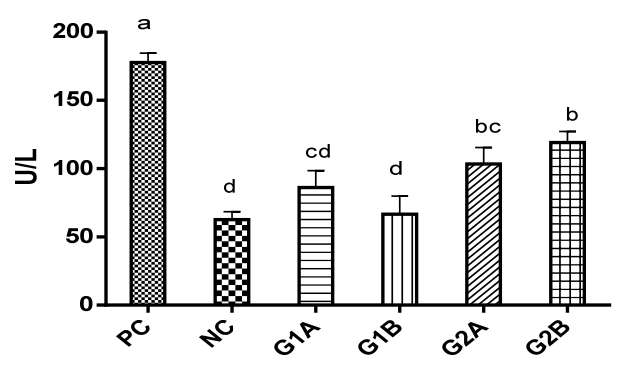

Figure 5: Mean serum ALT (U/L $\pm S E M)$ levels. PC: positive control group ( $\mathrm{CCl}_{4}$ only), $\mathrm{NC}$ : negative control group (untreated), G1A: desi Cicer arietinum L. extract group (300 mg/kg), G1B: desi Cicer arietinum L. extract group (150 mg/kg), G2A: kabuli Cicer arietinum L. extract group $(300 \mathrm{mg} / \mathrm{kg}$ bwt), and G2B: kabuli Cicer arietinum L. extract $(150 \mathrm{mg} / \mathrm{kg})$. All treatments were given orally for 21 days

\section{Changes in serum AST}

As shown in Figure 6, significant $(p \leq 0.05)$ decreases were seen in serum AST levels in G1B $(87.23 \pm 9.20 \mathrm{U} / \mathrm{L}), \mathrm{G} 1 \mathrm{~A}(111.86 \pm 13.40 \mathrm{U} / \mathrm{L})$ and G2B (116.28 $\pm 31.97 \mathrm{U} / \mathrm{L})$ groups, relative to PC group (165.24 \pm 16.43$)$. Serum ALT decreased in G2A group, when compared to PC group, but the decrease was not statistically significant.

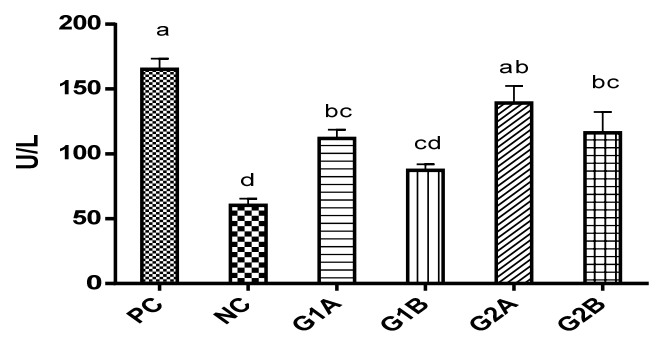

Figure 6: Mean serum AST levels. Values are expressed as (U/L $\pm S E M)$. PC: positive control $\left(\mathrm{CCl}_{4}\right.$ only), NC: negative control group (untreated), G1A: desi Cicer arietinum L. extract group (300 mg/kg), G1B: desi Cicer arietinum L. extract group (150 $\mathrm{mg} / \mathrm{kg}$ ), G2A: kabuli Cicer arietinum L. extract group (300 mg/kg), and G2B: kabuli Cicer arietinum L. extract $(150 \mathrm{mg} / \mathrm{kg})$. All treatments were given orally for 21 days 


\section{Catalase}

Significant $(p \leq 0.05)$ increases were observed in serum catalase in G1B (3.20 \pm 0.23$)$ and $G 1 A$ $(2.93 \pm 0.17)$ groups, when compared to PC group, while serum catalase activity was comparable among the negative control, G2A, G2B and PC groups. These results are shown in Figure 7.

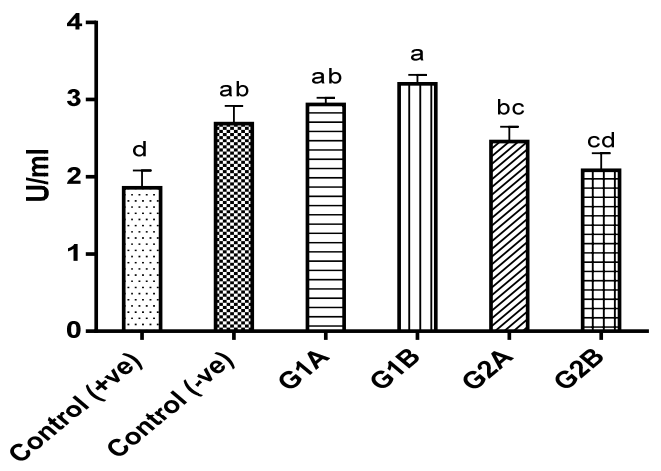

Figure 7: Mean serum catalase activities. Values are expressed as $(\mathrm{U} / \mathrm{mL} \pm \mathrm{SEM})$. PC: positive control group $\left(\mathrm{CCl}_{4}\right.$ only), NC: negative control group (untreated), G1A: desi Cicer arietinum L. extract group (300 mg/kg), G1B: desi Cicer arietinum L. extract group (150 mg/kg), G2A: kabuli Cicer arietinum L. extract group (300 mg/kg), and G2B: kabuli Cicer arietinum L. extract $(150 \mathrm{mg} / \mathrm{kg})$. All treatments were given orally for 21 days
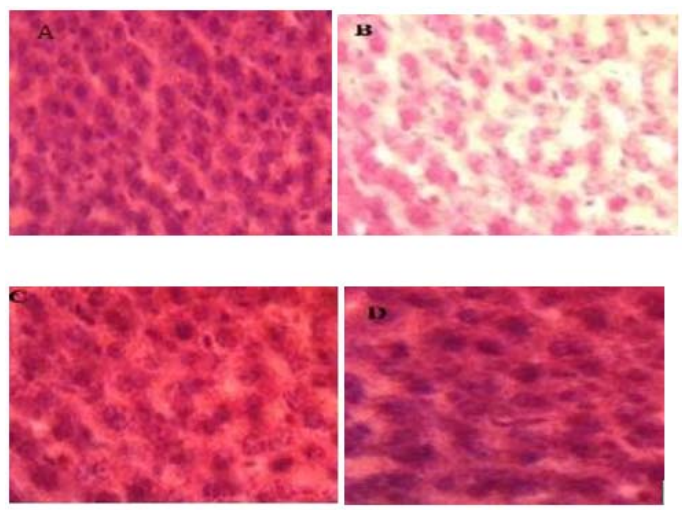

Figure 8: Effect of various treatments on liver histopathology. A: normal liver cells; $\mathrm{B}$ : $\mathrm{CCl}_{4}$-induced hepatotoxicity; C: lower dose desi chick pea oral treatment $(150 \mathrm{mg} / \mathrm{kg})$; D: higher dose desi chick pea oral treatment $(300 \mathrm{mg} / \mathrm{kg})$

\section{DISCUSSION}

Ethanolic extract yield varied significantly among cultivars of desi and kabuli (Cicer arietinum L.) in the current study. Overall, percentage extract yield of kabuli Cicer arietinum L. was significantly higher than that of desi Cicer arietinum L. cultivar. The findings on the percent yield in this study are in close agreement with previously published report [18].

In the current study, the percent yield of Cicer arietinum L. was higher in $80 \%$ aqueous ethanol than the yield in absolute ethanol. This is due to the lower polarity of absolute ethanol, when compared to $80 \%$ aqueous ethanol. Therefore, $80 \%$ ethanol, rather than absolute ethanol is usually used for the extraction of bioactive compounds from fruits and plants, mainly due to its good match, in nature and polarity with naturally occurring anti-oxidative compounds [19]. Antioxidants derived from plants are mostly polar. Phenolic and flavonoid compounds are extracted in $80 \%$ ethanol. The bioactive potential of these compounds (phenolic and flavonoids) play vital roles in beneficial effects of legumes [20].

In the current study, Cicer arietinum L. extract at high dose $(300 \mathrm{mg} / \mathrm{kg}$ bwt) mitigated the cytotoxic effects of $\mathrm{CCl}_{4}$-derived free radicals. Therefore, TOS level was highly decreased in G1A and G2A groups, when compared with the low extract dose (150mg/kg bwt) groups (G1B and G2B). Decreases observed in TOS levels at the higher dose of Cicer arietinum L. were comparable to NC. Higher dose of desi Cicer arietinum L. (balkasar) and kabuli Cicer arietinum L. (COOP6) tended to minimize the cytotoxic effects produced by $\mathrm{CCl}_{4}$ in rats. This might be due to the higher concentration of phenolic and flavonoids contents and subsequent scavenging activity of desi Cicer arietinum L. (balkasar) and kabuli Cicer arietinum L. (COOP-6), leading to reduction in TOS levels in the fragile microenvironment of $\mathrm{CCl}_{4}$-induced liver toxicity $[21,22]$. Total antioxidant capacity (TAC) of desi Cicer arietinum L. extract was significantly higher in G1A and G1B groups, when compared to PC, NC, G2A and G2B groups. The antioxidant capacity seen in the current study is comparable with those in a previous report [22]. The current results obtained are comparable to previous results for yellow soybean $(38.0 \mu$ Troloxeq $/ g$ and $94.9 \mu$ Troloxeq $/ g$ ) and $65 \mu$ Troloxeq $/ g$ for common beans [23-25]. It has been reported that higher levels of phenolic content activate the antioxidant enzymes, resulting in greater antioxidant capacity [26].

Serum ALT and AST levels were higher in PC than in NC, while serum levels of ALT and AST were decreased significantly in $\mathrm{G} 1 \mathrm{~A}$ and $\mathrm{G} 1 \mathrm{~B}$ groups, when compared to $\mathrm{PC}$, but the results were not comparable to NC. These results suggest normal and healthy hepatic enzyme 
levels, which confirms recovery from $\mathrm{CCl}_{4}$ induced hepatotoxicity. Serum ALT and AST levels were also reduced in $G 2 A$ and $G 2 B$ groups, when compared to $\mathrm{G} 1 \mathrm{~A}$ and $\mathrm{G} 1 \mathrm{~B}$ groups.

Serum catalase was also significantly higher in $\mathrm{G} 1 \mathrm{~A}$ and $\mathrm{G} 1 \mathrm{~B}$, relative to $\mathrm{PC}$ and other experimental groups. However, catalase level was high in G1A and G1B groups.

\section{CONCLUSION}

The ethanol extracts of high-yield cultivars of Cicer arietinum L. (desi and kabuli) are rich in phenolic compounds and flavonoids. Desi Cicer arietinum $\mathrm{L}$. has higher capacity for reducing oxidative stress and decreasing $\mathrm{CCl}_{4}$-induced increases in serum ALT and AST levels in rats. Thus, Cicer arietinum L. exerts its hepatoprotective effects in CCl4-treated rats through enhancement of antioxidant capacity. However, further investigations should be carried out to determine the hepatoprotective effect of Cicer arietinum L. in humans.

\section{DECLARATIONS}

\section{Acknowledgement}

We acknowledge support from Imtiaz Mustfa with respect to laboratory assay of hepatotoxicity parameters at Cell Biology Lab, Department of Physiology, Government College University, Faisalabad.

\section{Conflict of interest}

No conflict of interest is associated with this work.

\section{Contribution of authors}

We declare that this work was done by the authors named in this article and all liabilities pertaining to claims relating to the content of this article will be borne by the authors.

\section{Open Access}

This is an Open Access article that uses a funding model which does not charge readers or their institutions for access and distributed under the terms of the Creative Commons Attribution License (http://creativecommons.org/licenses/by/ 4.0) and the Budapest Open Access Initiative (http://www.budapestopenaccessinitiative.org/rea d), which permit unrestricted use, distribution, and reproduction in any medium, provided the original work is properly credited.

\section{REFERENCES}

1. Hemeda HM, Mohamed EF. Functional attribute of chickpea and defatted soybean flour blends on quality characteristics of shortening cake. Eur J Appl Sci 2012; 2(2): 44-50.

2. Mozaffarian D, Appel LJ, Van Horn L. Components of a cardioprotective diet: new insights. Circulation 2011; 123(24): 2870-2891.

3. Siddiq M, Ravi R, Harte JB, Dolan KD. Physical and functional characteristics of selected dry bean (Phaseolus vulgaris L.) flours. LWT-Food Sci and Tech 2010; 43: 232-237.

4. Zhang X, Shang $P$, Qin F, Zhou Q, Gao B, Huang $H$, Shi $Y H, Y u$ LL. Chemical composition and antioxidative and anti-inflammatory properties of ten commercial mung bean samples. LWT-Food SciTech 2013; 54: 171-178.

5. Butt MS, Batool R. Nutritional and functional properties of some promising legumes protein isolates. Pak JNutr2010; 9(4): 373-379.

6. Suneja Y, Kaur S, Gupta AK, Kaur N. Levels of nutritional constituents and antinutritional factors in black gram (Vigna mungo L. Hepper). Food Res Inter 2011; 44(2): 621-628.

7. Reynolds K, Chin A, Lees KA, Nguyen A, Bujnowski D, He J. A meta-analysis of the effect of soy protein supplementation on serum lipids. Am J Cardiol 2006; 98(5): 633-640

8. Rochfort S, Panozzo J. Phytochemicals for health, the role of pulses. J Agri Food Chem2007; 55(20): 79817994.

9. Imrie B. The New Rural Industries, $A$ handbook for farmers and investors, Black gram 2005.

10. Kulsum MU, Baque MA, Karim MA. Effects of different nitrogen levels on the morphology and yield of blackgram. JAgron2007; 6(1): 125.

11. Akaerue Bl, Onwuka Gl. Evaluation of the yield, protein content and functional properties of mungbean [Vigna radiata (L.) Wilczek] protein isolates as affected by processing. Pak JNutr2010; 9(8): 728-735.

12. Udensi EA. Effects of fermentation and germination on the physicochemical properties of Mucunacochinchinensis protein isolate. Afri $J$ Biotech 2006; 5(10): 896.

13. Siddhuraju P, Becker K. Antioxidant properties of various solvent extracts of total phenolic constituents from three different agroclimatic origins of drumstick tree (Moringa oleifera Lam.) leaves. J Agri Food Chem2003; 51(8): 2144-2155.

14. Abdolrasoul HE, Ebrahim HE, Zahra D, Fereshteh JK, Asma M, Hossein B. Composition and antioxidant and antimicrobial activity of the essential oil and extracts of Stachysinflata Benth from Iran. Food Chem 2010; 119(2): 452-458.

15. https://www.aalas.org/about-aalas/mission--ethics 
16. Anwar H, Rahman ZU, Javed I, Muhammad F. Effect of protein, probiotic and symbiotic supplementation on serum biological health markers of molted layers. Poultry Sci 2012; 91(10): 2606-2613.

17. Goth L. A simple method for determination of serum catalase activity and revision of reference range. ClinChimActa1991; 196(2-3): 143-151.

18. Yasmeen A, Yaseen T, Faisal M, Nazir S, Usman $S$, Nasreen Z, Ali S. Comparison of nutritional and dietary fiber composition of commonly consumed cereals and legumes. Pak J Sci Ind Res, Series B: Bio Sci 2017; 60(2): 119-121.

19. Zhou K, Yu L. Total phenolic contents and antioxidant properties of commonly consumed vegetables grown in Colorado. LWT 2006; 39: 1155-1162.

20. Awika JM, Rooney LW, Wu X, Prior RL, CisnerosZevallos $L$. Screening methods to measure antioxidant activity of sorghum (Sorghum bicolor) and sorghum products. J Agri Food Chem2003; 51(23): 6657-6662.

21. Macar TK, Macar O, Mart, DI. Variability in Some Biochemical and Nutritional Characteristics in Desi and Turkish Kabuli Chickpea (Cicer arietinum L.) Types. Celal Bayar Üniversitesi Fen Bilimleri Dergisi 2017; 13(3): 677-680.
22. Aguilera $Y$, Dueñas M, Estrella I, Hernández T, Benitez $V$, Esteban RM, Martín-Cabrejas MA. Phenolic profile and antioxidant capacity of chickpeas (Cicer arietinum L.) as affected by a dehydration process. Plant FoodsHumNutr2011; 66(2): 187-195.

23. Xu B, Chang SK. Total phenolics, phenolic acids, isoflavones, and anthocyanins and antioxidant properties of yellow and black soybeans as affected by thermal processing. J Agri Food Chem 2008; 56(16): 7165-7175.

24. Xu B, Chang SK. Total phenolic, phenolic acid, anthocyanin, flavan-3-ol, and flavonol profiles and antioxidant properties of pinto and black beans (Phaseolus vulgaris L.) as affected by thermal processing. J Agri Food Chem 2009; 57(11): 4754-4764.

25. Aguilera $Y$, Dueñas M, Estrella I, Hernández T, Benitez V, Esteban RM, Martín-Cabrejas MA. Evaluation of phenolic profile and antioxidant properties of Pardina lentil as affected by industrial dehydration. J Agri Food Chem 2010; 58(18): 10101-10108.

26. Song MH, Kim HN, Lim Y, Jang IS. Effects of coenzyme Q10 on the antioxidant system in $S D$ rats exposed to lipopolysaccharide-induced toxicity. Lab Animal Res 2017; 33(1): 24-31. 